\title{
X-linked colour vision deficiency (CVD) in some government school children of Nepal.
}

\author{
Sushil K ${ }^{1^{*}}$, Sushma $D^{2}$, Rani $\mathbf{G}^{1}$ \\ ${ }^{1}$ Department of Physiology, Kathmandu Medical College and Teaching Hospital, Sinamangal, Kathmandu, Nepal \\ ${ }^{2}$ Department of Pharmacology, Gandaki Medical College and Teaching Hospital, Nepal
}

\begin{abstract}
The X-linked colour vision deficiencies have different frequency and incidence in various locations and different castes. A total of 386 Nepalese children including 214 males and 172 females between ages 10-16 years were evaluated and screened for X-linked CVD in different government schools. An individual child was presented with the Ishihara's 38 Plates edition under normal day light from a distance of $75 \mathrm{~cm}$ and single plate was shown to them for 5 seconds. Among 214 boys, 13 (6.07\%) were colour deficient. Among 172 girls, 4(2.32\%) were colour deficient. The prevalence of colour vision deficiency in school children shows the importance of proper screening in schools.
\end{abstract}

Keywords: Ishihara's plates, X-linked colour vision deficiency.

Accepted on January 02, 2018

\section{Introduction}

The special ability of human beings to perceive in different colours distinguishes humans from other species. It is the ability to distinguish a light stimulus and variations of its different wavelength [1]. Colour vision deficiency (CVD) is a term which is not actual colour blindness but there are abnormalities in the development of one or more sets of retinal cones. It is a sex-linked condition. The genes that produce photo pigments are carried on the $\mathrm{X}$ chromosome; if some of these genes are missed color deficiency will be expressed in males with a higher probability than in females because males only have one $\mathrm{X}$ chromosome [2,3]. The popular Helmholtz theory of colour vision believes in the presence of three kinds of cones, each of the cones having a particular photo pigment which is primarily sensitive to one of the three primary colours. Normal colour vision is incorporated by three types of cone photoreceptors short- (S), middle- (M), and long- (L) wavelength-sensitive of $415 \mathrm{~nm}, 530 \mathrm{~nm}$ and $560 \mathrm{~nm}$, respectively. Green, blue and red are called primary colours as any colour can be produced by mixing appropriate proportion of these three colours [4]. The usual terms which are used to describe CVD are protanopia, deuteranopia and tritanopia. A protanope can be distinguished in having abnormal longer wavelength cone photo-pigment and a deuteranope and a tritanope have abnormal middle and shorter wavelength cone photo-pigments [5,6]. Red-green colour deficiency genes are located on the $23^{\text {rd }}$ chromosome on the long arm of the X-chromosome within the X928 band because of which a male who possesses a colour vision deficiency has the abnormal gene on the X-chromosome and a female who poses a CVD has the abnormal gene located on both the $\mathrm{X}$-chromosomes [7].

\section{Methods}

A descriptive study was conducted in government school children of Bhaktapur after getting approval from Institutional Review Committee (IRC) of Kathmandu Medical College.
Informed written consent in local language was taken before gathering the data. The study was carried out in May-July, 2017. An individual child was shown the complete plates of Ishihara's under normal day light from the distance of $75 \mathrm{~cm}$. Time permitted for identifying each plate by the child was 5 seconds. The types of color vision deficiency were interpreted by the help of key provided. The test was done as mentioned by Ishihara $[8,9]$.

\section{Results}

In our study 386 government school children (Males 214, females 172, age 10-16 years), from two schools of Bhaktapur, Nepal was evaluated for X-linked color vision deficiency. The incidence of color vision deficiency among the study children showed higher prevalence in male children. Among 214 males, $13(6.07 \%)$ were colour deficient (Figure 1). Among 172 females, $4(2.32 \%)$ were colour deficient. Out of color deficient, 04 were deuteranopia, 09 were deuteranomaly and 04 were protanomaly (Figure 2) (Table 1).

\section{Discussion}

The prevalence of X-linked color vision deficiency in the different castes, ethnic groups and countries are found to be different: in our present study the incidence of color vision deficiency in the male children $(6.07 \%)$ were found to be little high as found by Niroula and Saha $(3.8 \%)$ in Pokhara, Nepal [10]. In the present study the prevalence of X-linked color vision deficiency among female children (3.12\%) were found to be similar with some researches done in Saudi Arabia $(0.75 \%)$ by Oriowo and Alotaibi in 2008 [11]. It has shown that Asian males have an incidence of color vision defects of $4.9 \%$ compared to $0.6 \%$ in females. The prevalence of colordeficiency is around $8 \%$ in Europeans. It is found to be present in $4 \%$ of Africans; Studies has shown that it is between $2 \%$ and $7 \%$ with an average of $5.6 \%$ in South-West Asian populations; between $3 \%$ and $6 \%$ in populations of East Asia and South- 
Citation: Sushil K, Sushma D, Rani G. X-linked colour vision deficiency (CVD) in some government school children of Nepal. Biol Med Case Rep. 2018;2(1):12-14.

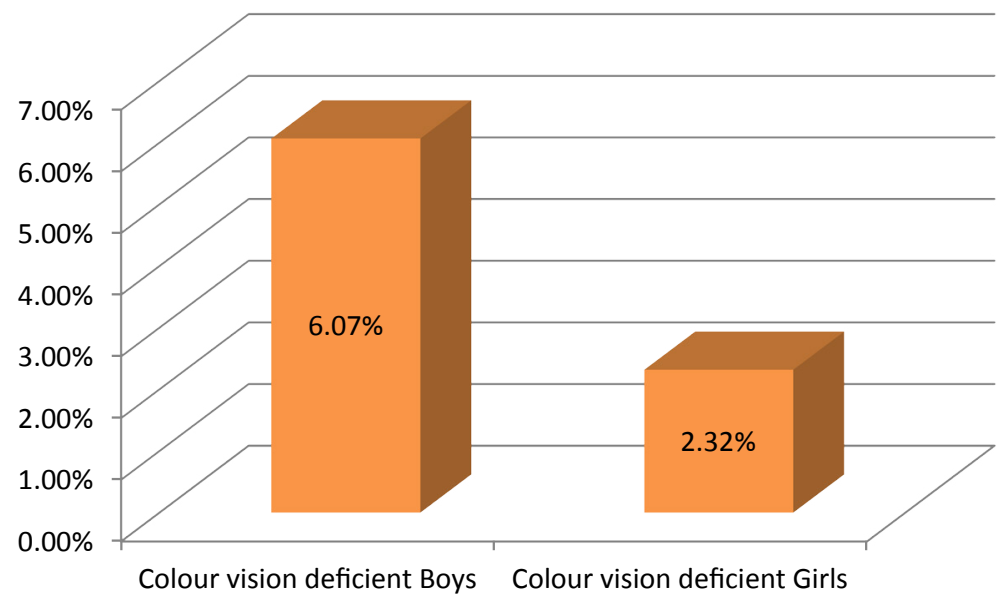

Figure 1. Comparison of X-linked color vision deficiency (CVD) among males and females of the study population (N=386).

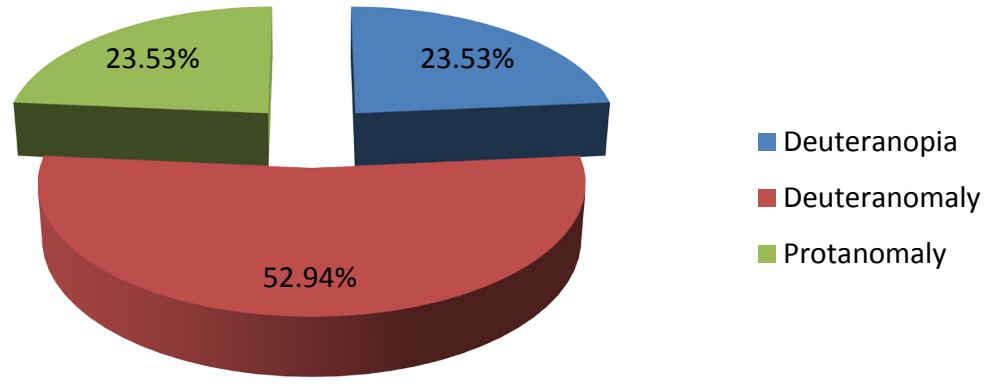

Figure 2. Distribution of different types of X-linked color vision deficiency (CVD) among the school children.

Table 1. Incidence of X-linked colour vision deficiency among the government school children. $(N=386)$.

\begin{tabular}{|c|c|c|c|c|c|}
\hline Subjects & Normal colour vision & Colour deficient & Deuteranopia & Deuteranomaly & Protanomaly \\
\hline Boys (214) & 201 & 13 & 03 & 08 & 02 \\
\hline Girls (172) & 168 & 04 & 01 & 01 & 02 \\
\hline Total (386) & 336 & 17 & 04 & 09 & 04 \\
\hline
\end{tabular}

East Asia [12]. The present study provides a detailed scenario of colour vision deficiency for the first time among male and female government school children of Bhaktapur district. Male children tend to have higher CVD prevalence which postulates the fact of $\mathrm{X}$-linked recessive nature.

\section{Conclusion}

$\mathrm{X}$-linked colour vision deficiency (CVD) can cause difficulty in school where colours are used in learning and teaching processes. Many jobs require accurate colour identification. A proper screening is needed in order to find the actual prevalence of CVD in school children so that in future, colour deficient people can avoid certain career like Pilots, Pathologists, Textile engineers, etc.

\section{Acknowledgements}

This study was conducted in government school children of Bhaktapur. We sincerely acknowledge to all school children who helped us to accomplish this study.

\section{References}

1. Cumberland P, Rahi JS, Peckham CS. Impact of congenital colour vision defects on Occupation. Arch Dis Child. 2005;90:906-8.
2. Taylor WOG. Effects on employment of defects in color vision. Br J Ophthalmol. 1971;55:753-60.

3. Holroyd E, Hall DMB. A re-appraisal of screening for color vision impairments. Child Care Health Dev. 1997;23:391-8.

4. Ganong WF. Review of Medical Physiology. (20th ed). New York: McGraw-Hill Medical, USA. 2001.

5. Margrain TH, Birch J, Owen CG. Colour vision requirements of firefighters. Occup Med-C. 1996;46:114-24.

6. Kalloniatis M, Luu C. Webvision: The organisation of the retina and visual system. Salt Lake City (UT): University of Utah Health Sciences Center, USA.

7. Neitz J, Neitz M. The genetics of normal and defective colour vision. Vision Res. 2011;51:633-51.

8. Ishihara S. Tests for color-blindness. Handaya, Tokyo, Hongo Harukicho, Japan.

9. Natu M. Colour blindness- A rural prevalence survey. Indian J Ophthalmology. 1987;35:71-3.

10. Niraula D, Saha CG. The incidence of colour blindness among some school children of Pokhara, West Nepal. Nepal Med Coll J. 2010;12:48-50. 
11. Oriowo OM, Alotaibi AZ. Colour vision screening among Saudi Arabian children. The South African Optometrist. 2008;67:56-61.
12. Bhasin MK. Genetics of castes and tribes of India: A review of population. Int J Hum Genet. 2006;6:81-8.

\section{*Correspondence to:}

\section{Sushil K}

Department of Physiology

Kathmandu Medical College and Teaching Hospital

Sinamangal

Kathmandu

Nepal

Tel: +977 1-4476152

E-mail: drsushilkharel@gmail.com 